\title{
Community attitudes towards the reintroduction programme for the Endangered pepperbark tree Warburgia salutaris: implications for plant conservation in south-east Zimbabwe
}

A. MAROY I

\begin{abstract}
The pepperbark tree Warburgia salutaris is categorized as Endangered on the IUCN Red List, primarily because of human-induced habitat degradation and over-collection for herbal medicine. Benefits from the reintroduction programme for the species in Tanganda Halt, on the edge of the Mutema Highlands in south-east Zimbabwe, are unequally distributed. This has influenced the attitudes of the local people towards the project and any future plant conservation initiatives. People receiving indirect benefits from the programme expressed positive attitudes towards $W$. salutaris for cultural, aesthetic and ecological reasons; those receiving direct benefits cited positive impacts on their household welfare. If the reintroduction programme for $W$. salutaris is to play a part in sustainable development in Tanganda Halt then inequalities in the distribution of benefits need to be addressed. The $W$. salutaris reintroduction programme is still evolving. Evaluating the attitudes of local people towards the programme provides valuable insights for development planning and for future plant conservation programmes in south-east Zimbabwe.
\end{abstract}

Keywords Community attitudes, pepperbark tree, plant conservation, reintroduction, sustainable development, Warburgia salutaris, Zimbabwe

\section{Introduction}

The pepperbark tree Warburgia salutaris (Bertol. f.) 1 Chiov is categorized as Endangered on the IUCN Red List (Hilton-Taylor et al. 1998), primarily because of human-induced habitat degradation and over-collection for herbal medicine. At the national level $W$. salutaris is categorized as Vulnerable in Mozambique (Izidine \& Bandeira, 2002), Endangered in Malawi (Msekandiana \& Mlangeni, 2002) and South Africa (Walter \& Gillet, 1997), Critically Endangered in Swaziland (Dlamini \& Dlamini, 2002) and Extinct in the Wild in Zimbabwe (Maroyi, 2008).

A. Maroyi Department of Biodiversity, School of Molecular and Life Sciences, University of Limpopo, Private Bag X1106, Sovenga 0727, South Africa. E-mail alfred.maroyi@ul.ac.za

Received 15 September 2010. Revision requested 16 December 2010.

Accepted 5 April 2011. First published online 2 December 2011.
The tree has been recorded in Malawi, Mozambique, South Africa, Swaziland, Zambia and Zimbabwe (Palgrave, 1983). Its bark is so much in demand that trees in protected areas are often stripped and destroyed by collectors. It has been recorded as one of the most administered medicinal plants in Zimbabwe and southern Africa (Marshall, 1998; Mukamuri, 1998).

There is little information on W. salutaris in Zimbabwe. Goldsmith \& Carter (1981) described the tree as rare and confined to south-eastern Zimbabwe. W. salutaris has been recorded in only one locality (Mutema Highlands, near Tanganda Tea Estate), although there is an unconfirmed record in Chipinge (Maroyi, 2000). This tree species occurs in the ecotone between woodland and rainforest at low altitudes. This is a rare habitat in Zimbabwe and therefore the species is likely to have been rare in the country (Maroyi, 2000). Reports on the conservation status of $W$. salutaris in Zimbabwe (Maroyi, 2000; Mapaura \& Timberlake, 2002) indicated that the species has been over-harvested for medicinal purposes. $W$. salutaris became locally extinct in Zimbabwe in the 1990s, resulting in bark supplies being imported from the Mozambican side of Chimanimani mountains (Mukamuri, 1998; Cunningham, 2001). The destruction of $W$. salutaris populations is not only a conservation problem but also a matter of concern to local people and traditional healers as it means loss of herbal medicine and a source of livelihood.

In 1997 a pilot project was initiated under the auspices of WWF-Zimbabwe and the local Zimbabwean NGO SAFIRE (Southern Alliance for Indigenous Resources) to reintroduce W. salutaris to south-eastern Zimbabwe, its historical habitat. A reintroduction is an attempt to establish a species in an area that was once part of its historical range but from which it has been extirpated or become extinct (IUCN, 1998). The overall aim of any reintroduction is to re-establish a viable and selfsustaining population that requires minimal long-term management. $W$. salutaris was not, however, reintroduced to native forests, where lack of individual rights to the species would probably lead again to over-harvesting, but into the home gardens of local farmers.

This reintroduction is an example of how home gardens growing threatened plants ex situ can be connected to conservation and livelihoods through circa-situ means (Hamilton, 2004). This community-based natural resource 
management involving $W$. salutaris aimed to secure the species into cultivation as a short-term measure while simultaneously diffusing threats from overexploitation. It is within this context that I evaluated attitudes of a community in south-eastern Zimbabwe towards the reintroduction of their most valued tree species, focusing on local perceptions and beliefs regarding the need for conservation of the species. As the area has more than a decade's history of implementing the reintroduction programme for $W$. salutaris there is an opportunity to gain insights into the achievements, constraints and general evolution of this approach.

\section{Study area}

The study was conducted in Tanganda Halt, which lies c. $30 \mathrm{~km}$ north-west of Chipinge town in the Manicaland province of Zimbabwe. It has a good road network that links the area with the towns of Chipinge, Chiredzi, Masvingo, Mutare and Chimanimani. The study area lies in Agro-ecological Region IV, a semi-extensive farming region characterized by low rainfall and periodical seasonal droughts and severe dry spells (Vincent \& Thomas, 1961). It is at c. $700 \mathrm{~m}$ altitude, with a mean annual rainfall of $450 \mathrm{~mm}$ concentrated in the rainy season from November to March. In the hottest month, October, the mean temperature is $32^{\circ} \mathrm{C}$, and in the coldest month, July, the mean temperature is $15^{\circ} \mathrm{C}$. In 2002 Tanganda Halt had 423 households and a population of 2,388 (CSO, 2002). Households have small permanent arable fields, typically of c. 3 ha. Traditional beliefs in Tanganda Halt are still prevalent, although some people practice Christianity.

Tanganda Halt is on the edge of the Mutema Highlands, the only documented historical locality of $W$. salutaris in Zimbabwe (Maroyi, 2000). Residents of Tanganda Halt rely heavily on the natural resources of these Highlands. The poorest families harvest construction timber, firewood and fencing materials, as well as their daily food and medicine. Soils are largely derived from granitic-gneissic rocks, giving rise to predominantly sandy soils with a low water-holding capacity, low fertility, low $\mathrm{pH}$ and deficiencies in nitrogen, phosphorus and sulphur (Grant, 1981).

The most extensive vegetation type is open mopane woodland and Acacia-Combretum woodland. The grass cover has suffered from overgrazing and bush encroachment. Poor and erratic rainfall in the area means that the study site has marginal potential for both cattle and crop production. Small areas of land are irrigated and livestock production is intensive because of crowding and overstocking. This has resulted in degradation of land and resources. With poverty, low levels of economic activity and the poor quality of available land, non-farm activities are potentially an important source of income.

\section{Methods}

During June-August 2008 I carried out a survey, using interviews, with 58 households $(13.7 \%$ of the total number of households) in Tanganda Halt to probe perceptions of, and attitudes towards, the reintroduction programme for $W$. salutaris. A survey map was generated in consultation with village leaders. The households were marked on the map and, beginning with a random number between 1 and 10, every 7 th household was selected. Only one adult member of each household was interviewed. The interview was structured and comprised both open and closed questions (Table 1). The wording and ordering of questions were designed to avoid asking leading questions and/or priming interviewees for particular responses. Interviewees comprised both males $(38 \%)$ and females $(62 \%)$, with an age range of 33-82 years (median $=53$ ). The households were selected using wealth ranking (Grandin, 1988) to ensure that different wealth categories were represented in the study. Verbal informal consent was obtained from each participant. I explained the purpose of the interview and, if the person was willing to participate, the interview proceeded. Each interview lasted 30-50 minutes and took the form of a conversation structured around the questions. The interview gave respondents latitude to describe their responses using terms and language most familiar to each of them, and not bound to predetermined answers (Mikkelsen, 1995).

In addition, five group discussions were conducted. These focused on group perceptions of the reintroduction programme, uses of $W$. salutaris, conservation issues and prospects for the success of the project. Each of these discussions lasted c. 1-2 hours and involved 3-8 informants who had particular knowledge about the reintroduction programme.

Interview data were coded and sorted into themes immediately after the fieldwork. The main categories of

TABLE 1 Questions used to guide the semi-structured interviews with residents of Tanganda Halt, south-eastern Zimbabwe.

Are they any Warburgia salutaris trees in this village?

If yes, how many are there?

Do you know any traditional uses of $W$. salutaris?

If yes, could you please give details?

Who uses these products?

How do users obtain these products?

Do you know that $W$. salutaris is threatened?

If yes, how do you know about this?

Do you think that $W$. salutaris should be protected?

If yes, how do you think this can be done?

Do you know that $W$. salutaris was reintroduced into this area in 1997 ?

How do you feel about the reintroduction project?

Do you think they are lessons that can be drawn from the relationship of people with $W$. salutaris? 
answers were listed and the number of responses tabulated. Inconsistencies and unique statements were noted and given particular attention. When people gave multiple responses to a question the responses were aggregated by topic. Because much of the data collected were descriptive, they did not require further analysis. The data were analysed by looking for themes and reoccurring issues. I also examined secondary sources of information such as reports on the reintroduction programme.

\section{Results}

The need to conserve $W$. salutaris was ubiquitously perceived, with all respondents reporting its contribution towards their livelihoods, medicine and cultural heritage (Table 2). Almost all those interviewed (98.3\%) claimed to have seen $W$. salutaris at some stage in their lives and only one respondent was uncertain as to whether she had seen it or not. There was a general consensus that the current level of cultivation of the species in Tanganda Halt is insufficient to meet demand. Only limited plantings have occurred and respondents estimated the total number of surviving $W$. salutaris in Tanganda Halt to be seven, all grown from seedlings donated in 1997. According to Dhliwayo, the local chairman of the Zimbabwe Traditional Healers Association, a total of 30 seedlings were donated under the WWFZimbabwe SAFFIRE project (he personally received four but only one survived). Termites were responsible for most of the deaths (Dhliwayo, pers. comm.). No other seedlings have been introduced since 1997. W. salutaris is known to be difficult to propagate (Crouch \& Edward, 2004; Symmonds \& Crouch, 2005). All the seedlings came from South Africa.

TABle 2 Details of the various uses for different parts of W. salutaris reported by people living in Tanganda Halt. Some respondents indicated more than one use.

\begin{tabular}{|c|c|c|}
\hline Part & Uses & $\begin{array}{l}\text { Response } \\
(\%), n=67\end{array}$ \\
\hline \multirow[t]{5}{*}{ Bark/leaves } & $\begin{array}{l}\text { Decoction used as remedy } \\
\text { for all diseases }\end{array}$ & 22.4 \\
\hline & $\begin{array}{l}\text { Decoction used to treat } \\
\text { venereal disease }\end{array}$ & 10.4 \\
\hline & $\begin{array}{l}\text { Boiled, taken to treat cold, } \\
\text { fever \& malaria }\end{array}$ & 6.0 \\
\hline & $\begin{array}{l}\text { Powder taken by mouth as } \\
\text { cure for sores }\end{array}$ & 3.0 \\
\hline & $\begin{array}{l}\text { Dried \& ground, taken as } \\
\text { snuff to clear sinuses }\end{array}$ & 1.5 \\
\hline $\begin{array}{l}\text { Entire tree \& its } \\
\text { different parts }\end{array}$ & Cultural preservation & 7.5 \\
\hline Leaves & $\begin{array}{l}\text { Sold to other community } \\
\text { members \& outsiders }\end{array}$ & 47.8 \\
\hline Roots/bark/leaves & $\begin{array}{l}\text { Boiled roots/bark/leaves taken } \\
\text { to treat malaria }\end{array}$ & 1.5 \\
\hline
\end{tabular}

The surviving trees are in the home gardens of traditional healers and of a few enthusiastic plant growers and smallholders. Because of cultural beliefs surrounding the use of $W$. salutaris the plants are often planted in secluded spots of the home garden and are not mixed with vegetables or other food crops. One respondent, a traditional healer, had two mature $W$. salutaris trees in his home garden. $\mathrm{He}$ wanted to have easy access to the tree to treat his patients, and for his own use and that of his neighbours and family members. The majority of respondents faced great challenges in raising the donated seedlings, with eight of nine respondents reporting losses in the first year of the programme. Nine of the 58 people interviewed received donated seedlings (1-4 per household). Despite their willingness to establish and manage $W$. salutaris trees, farmers were constrained by several factors. Among them were lack of seedlings, technical know-how, and financial and material resources. When asked what help the households would need to conserve $W$. salutaris, all requested seedlings.

Knowledge of the traditional uses of $W$. salutaris was reported by $89.7 \%$ of respondents but there were differences in people's perceptions of the value and use of the species (Table 2). Because of the scarcity of $W$. salutaris people are in some cases using leaves instead of the preferred stem or root bark. Fresh leaves are harvested and sold in small packets of 50-100 g. The harvested leaves or leaf and bark powder are sold in informal markets specializing in selling herbal medicines in major towns such as Bulawayo, Chipinge, Gweru, Harare and Mutare. W. salutaris is also bartered with neighbours in exchange for other commodities, and given to neighbours and relatives. This trade and exchange of $W$. salutaris products between households and relatives strengthens family relationships. The sale of products significantly improves family financial status, because cash income can be used by the household to buy food, clothing and pay school fees. The respondents emphasized that any seedling donations in future should benefit the underprivileged households in the area. The estimated net income from $W$. salutaris trade is USD 100-450 per annum per household. The majority of people who benefited from the donated $W$. salutaris seedlings in 1997 were already involved in medicinal plant cultivation or trade.

The majority of respondents were aware of the threatened status of $W$. salutaris (Table 3 ). Respondents appeared to be knowledgeable about the reintroduction programme, had a relatively good understanding of the importance of $W$. salutaris and believed it should be conserved, and generally held positive attitudes towards the programme (Table 3). Respondents provided a number of reasons to justify their attitudes (Table 4 ) but there were mixed feelings regarding the distribution of benefits from the programme (Table 5). Although the respondents supported 
TABle 3 People's attitudes towards the conservation of W. salutaris in Tanganda Halt.

\begin{tabular}{lc}
\hline $\begin{array}{l}\text { Question } \\
\text { Knowledge about threatened } \\
\quad \text { status of } \boldsymbol{W} \text {. salutaris }\end{array}$ \\
$\begin{array}{l}\text { Yes } \\
\text { No }\end{array}$ \\
Don't know & 86.2 \\
Knowledge of the reintroduction & 10.3 \\
$\quad$ programme & 3.3 \\
Yes & \\
No & \\
Attitude towards the reintroduction & 93.1 \\
$\quad$ programme & 6.9 \\
Positive & \\
Negative & 55.1 \\
Neutral & 25.9 \\
\hline
\end{tabular}

the reintroduction programme, few are benefiting from it. According to the respondents the most important factors that positively influence attitudes supporting reintroduction are: deriving direct benefits from the species and believing that the reintroduction programme would be good for the community. During group discussions participants reported that managing and preserving $W$. salutaris is not easy given the precarious livelihoods of the local community, lack of non-farm employment and high dependence on natural resources.

TABLE 4 Reasons given by people in Tanganda Halt to justify their attitudes towards the $W$. salutaris reintroduction programme. Some respondents provided more than one justification for their attitude.

\begin{tabular}{|c|c|}
\hline Reasons (by attitude) & $\begin{array}{l}\text { Response }(\%) \\
\mathrm{n}=65\end{array}$ \\
\hline \multicolumn{2}{|l|}{ Positive attitude } \\
\hline $\begin{array}{l}\text { W. salutaris helps to improve our livelihoods } \\
\text { through sale of its products }\end{array}$ & 43.1 \\
\hline $\begin{array}{l}\text { We want to preserve } W \text {. salutaris as it is an } \\
\text { important traditional medicine }\end{array}$ & 63.1 \\
\hline $\begin{array}{l}\text { We want to conserve } W \text {. salutaris for future } \\
\text { generations }\end{array}$ & 18.5 \\
\hline $\begin{array}{l}\text { W. salutaris is important for cultural } \\
\text { preservation }\end{array}$ & 35.4 \\
\hline W. salutaris has the right to live & 3.0 \\
\hline Neutral attitude & \\
\hline $\begin{array}{l}\text { W. salutaris is not different from other plants } \\
\text { Negative attitude }\end{array}$ & 1.5 \\
\hline $\begin{array}{l}\text { Only a few people are benefiting from } \\
W . \text { salutaris products }\end{array}$ & 73.8 \\
\hline Products of $W$. salutaris unaffordable & 50.8 \\
\hline $\begin{array}{l}\text { We do not have access to the products of } \\
\text { W. salutaris }\end{array}$ & 44.6 \\
\hline $\begin{array}{l}\text { Too much research has been done on } \\
\text { W. salutaris without any meaningful results }\end{array}$ & 3.0 \\
\hline
\end{tabular}

TABLE 5 Respondents' views of the benefits derived from the $W$. salutaris reintroduction programme in Tanganda Halt.

\begin{tabular}{lc}
\hline & Response (\%), \\
Benefit & $\mathrm{n}=58$ \\
\hline Income from sale of $W$. salutaris products & 8.6 \\
Using $W$. salutaris as medicine & 19.1 \\
No benefits & 53.5 \\
Pleasure to see (aesthetic) & 6.8 \\
Provides ecological service & 3.4 \\
Don't know & 8.6 \\
\hline
\end{tabular}

\section{Discussion}

This study shows that residents of Tanganda Halt are aware of the threatened status of $W$. salutaris and the need to conserve it. Those respondents who benefit economically from the species and its products were more positive about the reintroduction programme than those without such benefits. This suggests that as benefits to some people increase, those not receiving a share of the benefits become more disenchanted with the $W$. salutaris reintroduction programme and display more negative attitudes. The reintroduction programme did not benefit the poorest residents of Tanganda Halt and the surrounding areas of Mutema Highlands. These are the people most likely to be dependent upon natural resources and consequently those whose support for conservation is most needed if sustainable utilization of biodiversity is to be achieved. This is consistent with the findings by Dowie (2005) that poor people living adjacent to protected areas have often been overlooked in the implementation of conservation programmes. Before it went extinct locally some of the residents relied on the sale and use of $W$. salutaris for generating cash income. The issues surrounding reintroductions are complex, influenced by ecology, biology, sociology, economics, philosophy and ethics (Nie, 2003). The benefits of $W$. salutaris reintroduction go beyond the simple return of this species into farmers' home gardens or the wild because it affects the local economy and household livelihoods.

As major stakeholders in the conservation of $W$. salutaris the respondents, particularly those with limited alternative opportunities to generate income, felt that the reintroduction programme should be expanded if this species is to become a component of a sustainable land-use system. Several studies have demonstrated clear linkages between developmental programmes and positive attitudes towards conservation (Alexander, 2000; Mehta \& Heinen, 2001; Wang et al., 2006). The last few decades have seen rapidly escalating livelihood problems in Zimbabwe, drought, difficult socioeconomic conditions, problems faced by the health delivery system, AIDS and a declining national economy (Campbell et al., 1998). The result has been an increase in a variety of 
activities that provide cash income, particularly collection of medicinal plants. The popularity of, and high demand for, traditional medicines is evidenced by the increasing number of herbal clinics in both urban and rural areas (Mukamuri, 1998).

Exploitation of $W$. salutaris is a profitable activity in Zimbabwe, with the bark valued at USD $33 \mathrm{~kg}^{-1}$ (Cunningham, 2001). Preliminary economic analysis of the reintroduction of $W$. salutaris in south-eastern Zimbabwe suggested that the project has potential to enhance conservation of this threatened species and simultaneously improve the livelihoods of rural people (Veeman, 2002; Cunningham, 2004). This project has been evaluated as profitable and beneficial, with a benefit to cost ratio of $42: 1$ for traditional healers and 24: 1 for smallholders (Veeman, 2002). Respondents indicated that larger-scale cultivation is required if the national demand for the species as a medicinal plant is to be met. This could create new income opportunities for farmers interested in cultivation of the species for the growing market demand.

There are a wide variety of benefits from the $W$. salutaris reintroduction programme that help to reduce poverty or have the potential to do so: supply of subsistence goods, small-scale trade, and increase in social capital and human dignity. In many instances full-time engagement in forest-related activities has either lifted participant households out of poverty, or ensured that they have never been close to poverty (Shackleton, 2004). For programmes to be successful both in providing benefits to communities and protecting wild plant resources, not only must the benefit be received and valued but the linkage between the benefit and the wildlife resource must be clear. The community of Tanganda Halt is aware that $W$. salutaris provides benefits but most felt they were not the beneficiaries. In this context, participatory initiatives that try to offer something for everyone have not been as successful as expected (Shackleton et al., 2002). However, as the W. salutaris reintroduction programme is a community-based project, the local community require management options that both benefit the participants and strengthen the reintroduction programme. The social values of this species are important to consider at a time when most Zimbabweans are facing economic chaos, hyper-inflation and declining access to pharmaceutical medicines (Cunningham, 2004). In South Africa pills containing freeze-dried $W$. salutaris leaves are being used to treat secondary infections in patients with HIV (Cunningham, 2004). The main implication of this study for plant conservation in south-east Zimbabwe is that active involvement of the community in planning and decision making for management of a valuable species such as $W$. salutaris would enhance local people's perceptions of the reintroduction programme and thus, ultimately, its success.

\section{Acknowledgements}

I would like to thank the people of Tanganda Halt for their assistance and cooperation during data collection. I am also grateful to Dr A. Muroyiwa and two anonymous reviewers for constructive comments.

\section{References}

Alexander, S.E. (200o) Resident attitudes towards conservation and black howler monkeys in Belize: the community baboon sanctuary. Environmental Conservation, 27, 341-350.

Campbell, B.M., Byron, N., Hobane, P., Matose, F., Madzudzo, E. \& Willy, E. (1996) Taking CAMPFIRE Beyond Wildlife: What is the Potential? A paper presented at the Proceedings of the Pan-African Conference on Sustainable Use of Natural Resources and Community Participation, Harare, Zimbabwe.

Crouch, N.R. \& Edward, T. (2004) Ethnomedicinal (muthi) plant nurseries. In Indigenous Forests and Woodlands in South Africa: Policy, People and Practice (eds M.J. Lawes, H.A.C. Eeley, C.M. Shackleton \& B.G.S. Geach), pp. 658-678. University of KwaZuluNatal Press, Scottsville, South Africa.

CSO (Central Statistics Office) (2002) Preliminary Report, National 2002 Population Census. Government Printers, Harare, Zimbabwe.

Cunningham, A.B. (2001) Return of the pepperbark. Medicinal Plant Conservation, 7, 21-22.

Cunningham, A.B. (2004) Warburgia medicinal bark: Zimbabwean case. In Riches of the Forest: For Health, Life and Spirit in Africa (eds C. López \& P. Shanley), pp. 41-44. Centre for International Forestry Research, SMK Desa Putera, Indonesia.

Dlamini, T.S. \& Dlamini, G.M. (2002) Swaziland. In Southern African Plant Red Data Lists (ed. J.S. Golding), pp. 121-134. Southern African Botanical Diversity Network Report No. 14, Pretoria, South Africa.

Dowie, M. (2005) Conservation refugees: when protecting nature means kicking people out. Orion, 24, 16-27.

Goldsmith, B. \& Carter, D.T. (1981) The indigenous timber trees of Zimbabwe. The Zimbabwe Bulletin of Forestry Research, 9, 339.

Grandin, B.E. (1988) Wealth Ranking in Smallholder Communities: A Field Manual. Intermediate Technology Publications, London, UK.

Grant, P.M. (1981) The fertilization of sandy soils in peasant agriculture. Zimbabwe Agricultural Journal, 78, 169-175.

Hamilton, A.C. (2004) Medicinal plants, conservation and livelihoods. Biodiversity and Conservation, 13, 1477-1517.

Hilton-Taylor, C., Scott-Shaw, R., Burrows, J. \& Hahn, N. (1998) Warburgia salutaris. In IUCN Red List of Threatened Species v. 2010.4. Http://www.iucnredlist.org [accessed 9 May 2011].

IUCN (1998) IUCN Guidelines for Re-introductions. Prepared by the Species Survival Commission. IUCN, Gland, Switzerland, and Cambridge, UK.

Izidine, S. \& BAndeira, S.O. (2002) Mozambique. In Southern African Plant Red Data Lists (ed. J.S. Golding), pp. 43-60. Southern African Botanical Diversity Network Report No. 14, Pretoria, South Africa.

Mapaura, A. \& Timberlake, J. (2002) Zimbabwe. In Southern African Plant Red Data Lists (ed. J.S. Golding), pp. 43-60. Southern African Botanical Diversity Network Report No. 14, Pretoria, South Africa. 
Maroyi, A. (2000) Options for the recovery of Warburgia salutaris (pepperbark tree) populations in Zimbabwe. The Zimbabwe Science News, 34, 54-60.

Maroyi, A. (2008) Ethnobotanical study of two threatened medicinal plants in Zimbabwe. International Journal of Biodiversity Science and Management, 4, 1-6.

Marshall, N.T. (1998) Searching for a Cure: Conservation of Medicinal Wildlife Resources in East and Southern Africa. TRAFFIC International, Cambridge, UK.

Menta, J.N. \& Heinen, J.T. (2001) Does community-based conservation shape favourable attitudes among locals? An empirical study from Nepal. Environmental Management, 28, 165-177.

Miknelsen, B. (1995) Methods for Development Work and Research: A Guide for Practitioners. Sage Publications, London, UK.

Msenandiana, G. \& Mlangeni, E. (2002) Malawi. In Southern African Plant Red Data Lists (ed. J.S. Golding), pp. 135-156. Southern African Botanical Diversity Network Report No. 14, Pretoria, South Africa.

Mukamuri, B. (1998) Use of medicinal plants in Zimbabwe's urban and rural areas. The Zimbabwe Science News, 32, 42-45.

Nie, M.A. (2003) Beyond Wolves: The Politics of Wolf Recovery and Management. University of Minnesota Press, Minneapolis, USA.

Palgrave, K.C. (1983) Trees of Southern Africa. Struik, Cape Town, South Africa.

Shackleton, C.M. (2004) Assessment of the Livelihoods Importance of Forestry, Forests and Forest Products in South Africa. Unpublished Report to Rhodes University, Grahamstown, South Africa.

Shackleton, S., Campbell, B.M., Wollenberg, E. \& Edmunds, D. (2002) Devolution and community-based natural resource management: creating space for local people to participate and benefit? Natural Resources Perspectives (ODI), 76, 1-6.

Symmonds, R. \& Crouch, N. (2005) Warburgia salutaris. In Growing Rare Plants: A Practical Handbook on Propagating the Threatened Plants of Southern Africa (ed. G. Nichols), pp. 83-86. Southern African Botanical Diversity Network, Pretoria, South Africa.

VEEMAN, T. (2002) Muranga returns: the economics of producing a rare medicinal species reintroduced in south-eastern Zimbabwe. In Uncovering the Hidden Harvest: Valuation Methods for Woodland and Forest Resources (eds B.M. Campbell \& M.K. Luckert), pp. 146-148. Earthscan, London, UK.

Vincent, V. \& Thomas, R.G. (1961) An Agricultural Survey of Southern Rhodesia (Part 1): Agro-ecological Survey. Government Printers, Salisbury, Rhodesia.

W alter, K.S. \& Gillet, H.J. (1997) 1997 IUCN Red List of Threatened Plants. World Conservation Monitoring Centre, Cambridge, UK, and IUCN, Gland, Switzerland.

Wang, S.W., Lassoie, J.P. \& Curtis, P.D. (2006) Farmer attitudes towards conservation in Jigme Singye Wangchuck National Park, Bhutan. Environmental Conservation, 33, 148-156.

\section{Biographical sketch}

A. Maroyi's botanical interests are wide-ranging and include economic botany, plant ecology and systematics, and also conservation of plant species and of biodiversity in general. 